\title{
The Gender Wage Gap in Bulgaria: A Semiparametric Estimation of Discrimination
}

\author{
By: Dean Jolliffe
}

William Davidson Working Paper Number 401

July 2001 


\title{
The Gender Wage Gap in Bulgaria: A Semiparametric Estimation of Discrimination
}

\author{
Dean Jolliffe* \\ Economic Research Service, U.S. Department of Agriculture
}

Revised: July 23, 2001

\begin{abstract}
Bulgaria's transition to a market economy has coincided with a large increase in wage inequality. Given the emphasis on wage leveling in pre-transition Bulgaria, the rise in wage inequality may be due to managers rewarding more productive workers; or it may be the result of rewarding non-economic characteristics such as gender. Using data from the 1995, nationally representative Bulgaria Integrated Household Survey, I examine whether gender discrimination is an important factor determining the gap in wages between men and women and the extent to which gender discrimination affects wage inequality. I model wage determination with a correction for sample selection as a Type III Tobit and estimate this model with the Honore et al. (1997) semiparametric estimator. Unlike the classic Heckman correction for sample selection, this estimator is consistent in the presence of heteroscedasticity. I bootstrap to estimate standard errors. Using separate wage regression estimates for men and women, an Oaxaca decomposition indicates that women's wages are 25 percent lower than men's wages and 85 percent of this differential is due to discrimination, or more precisely, due to differences in how men and women are rewarded for the same characteristics.

Classification: I2, J16, C14

Key Words: $\quad$ Human Capital, Bulgaria, Wage Differentials, Discrimination, Gender, Sample Selection Model, Type 3 Tobit, Semiparametric Estimation

* I thank Peter Orazem, Anna Ratcheva, Nauro Campos, Josh Winicki, Craig Gundersen, Linda Ghelfi and Leslie Whitener for comments. I'm grateful to Avgoustina Tchoutkina for providing me with the 1998 Bulgarian Statistical Yearbook, and I also thank Bohdan Krushelnytskyy and Anastassia Semykina for excellent research assistance. The views and opinions expressed in this paper do not reflect the views of the Economic Research Service of the U.S. Department of Agriculture.
\end{abstract}

Correspondence: ERS-USDA, Room S-2059, 1800 M Street NW, Washington, DC 20036-5831 Email: Iolliffe@ers.usda.gov 


\section{SUMMARY}

The transition in Eastern Europe from centrally-planned to market economies has resulted in large increases in inequality. Milanovic (1998) states that the Gini coefficient of disposable income increased an average of nine points, from 24 to 33, over the period from 1987-88 to 1993-95. Milanovic also states that the rate of this increase was three times as great as the increase in inequality experienced in the West during the 1980s. In the case of Bulgaria, Milanovic (1999, Table 8) shows that the income Gini coefficient increased ten points, from 21.7 to 31.7 between 1989 and 1995 , and by decomposing this change in the Gini coefficient, he also shows that 78 percent of the increase in inequality is due to the change in the distribution of wages.

That inequality has increased during transition is to many observers not a surprise, and conventional wisdom might suggest that some increase in inequality was necessary to improve efficiency. The ability of firm managers to reward those workers who are more productive is an essential aspect of the market economy. If it is the case that the transition to a market economy results in more productive workers receiving greater pay, then one should expect to see an increase in wage inequality. Along with the ability to reward more productive workers, though, also comes the freedom to penalize or reward workers for reasons not related to economic performance. If firm managers used their increased freedom to set wages in a way that penalized workers for non-economic characteristics (for example, gender), then this too could explain the increase in wage inequality observed in Bulgaria.

The purpose of this paper is to estimate a model of wage determination in Bulgaria to first test the null hypothesis that the pay structure for men and women is the same. A rejection of this null hypothesis is evidence of gender discrimination, or that men and women with the same 
levels of education, experience, and other economically relevant factors receive different pay. After testing for discrimination, the observed male-female wage gap is decomposed into two components: 1. that which results from male-female differences in economic characteristics, such as education; and 2. that which results from different pay structures, or discrimination. The answer to these questions will provide evidence as to whether the increase in wage inequality results purely from managers rewarding more productive workers, and thus improving economic efficiency, or whether the increase in wage inequality results from managers rewarding noneconomic characteristics and thereby hampering the transition.

The semiparametric regression results show that male wages are about 25 percent greater than female wages. An Oaxaca decomposition of this differential shows that differences in economic characteristics, such as education, experience, or sector of employment, explain very little of this wage differential. To a large extent this is due to the fact that there is a history of equal access to education and employment opportunities in Bulgaria. The large majority, the preferred estimates indicate 85 percent, of this wage differential is explained by what is typically referred to as discriminatory practices. More accurately this difference is explained by the difference in the wage structures for men and women, or how men and women are rewarded differently for the same economic characteristic.

Figure 2 indicates that the distribution of wages would be essentially the same for women as for men if all women received an increase in wages of 21 percent to compensate for the discriminatory practices. Similarly, if women were paid according to the male wage schedule, the level of wage inequality would decline significantly. In considering the log of predicted wages, the Gini coefficient declines by 18 percent when female wages are predicted using the male wage structure. 


\section{Introduction}

The transition in Eastern Europe from centrally-planned to market economies has resulted in large increases in inequality. Milanovic (1998) states that the Gini coefficient of disposable income increased an average of nine points, from 24 to 33, over the period from 1987-88 to 1993-95. Milanovic also states that the rate of this increase was three times as great as the increase in inequality experienced in the West during the 1980s. In the case of Bulgaria, Milanovic (1999, Table 8) shows that the income Gini coefficient increased ten points, from 21.7 to 31.7 between 1989 and 1995, and by decomposing this change in the Gini coefficient, he also shows that 78 percent of the increase in inequality is due to the change in the distribution of wages.

Jones (1991, Table 5) provides further evidence of the dramatic increase in wage inequality by examining the coefficient of wage variation for 11 employment sectors in Bulgaria. His measure of wage dispersion is 0.12 for $1960,0.12$ for $1970,0.10$ in $1980,0.12$ in $1987 . \square_{\text {Jones }}$ then shows that in the early transition years of 1989 and 1990 this measure increased to 0.31 and 0.26 , respectively. Beleva, Jackman and Nenova-Amar (1995, Table 5-5) show that the dispersion of wages continued to increase dramatically from 1990 to 1992 . The coefficient of variation across 18 industries increased by 71 percent from 1990 to 1992. Jones asserts that the large increase in the dispersion of wages in 1989 was due in part to new legal arrangements (New System of Basic Wages) that gave managers much more control over determining the wages their employees would receive.

That inequality has increased during transition is to many observers not a surprise, and conventional wisdom might suggest that some increase in inequality was necessary to improve 
efficiency. The ability of firm managers to reward those workers who are more productive is an essential aspect of the market economy. If it is the case that the transition to a market economy results in more productive workers receiving greater pay, then one should expect to see an increase in wage inequality. ${ }^{2}$ Along with the ability to reward more productive workers, though, also comes the freedom to penalize or reward workers for reasons not related to economic performance. If firm managers used their increased freedom to set wages in a way that penalized workers for non-economic characteristics (for example, gender), then this too could explain the increase in wage inequality observed in Bulgaria.

Blau and Kahn (1992) present evidence that the large gender gap in the U.S. relative to Scandinavian countries and Australia is due to greater wage inequality in the U.S. In Central European countries, though, there is some empirical evidence that the increased level of inequality and changing distribution of wages has been associated with an improvement in the relative position of women. Orazem and Vodopivec (2000) show that during the early years of transition in Estonia and Slovenia, the large decline in real wages experienced by both countries coincided with the relative improvement of women's wages due to greater demand for bettereducated laborers.

In contrast to Estonia and Slovenia, the sociology literature suggests that in the case of Bulgaria, the changing wage structure has disproportionately harmed the position of women. Using data from the International Social Justice Project, a probability sample of the adult population in 1991 and 1996, Jasso (2000) considers a measure of justice which is a function of

\footnotetext{
${ }^{1}$ Jones asserts that these figures show a tight compression of wages relative to Western Europe, and also relative to other East European countries.

${ }^{2}$ Indeed there is some evidence that productivity increased during the early years of transition. Commander and Tolstopiatenko (1996) show that industrial output per worker increased by 6 percent between 1990 and 1994.

${ }^{3}$ In addition to benefiting from greater demand for skills in both Slovenia and Estonia, women also worked disproportionately in sectors that benefited from transition. Within sectors, though, women lost relative to men.
} 
reported wage income and the respondents perception of their 'just' wage. She shows that in 1991, Bulgarian men had a higher measure of injustice than women, but by 1996 this had reversed with women stating a higher level of injustice. Sziráczki and Windell (1992) provide evidence suggesting that the deteriorating position of women in Bulgaria may be the result of discriminatory practices. They report results from a survey of managers who were asked whether they had a preference for men or women when hiring for production or professional work..$^{\square}$ While 25 percent stated a preference for hiring women for skilled production work, 54 percent stated a preference for hiring men. In the case of recruiting professional staff, 59 percent of the managers stated that they would prefer to hire a man rather than a woman, while only three percent stated a preference for hiring a woman.

The purpose of this paper is to estimate a model of wage determination in Bulgaria to first test the null hypothesis that the pay structure for men and women is the same. A rejection of this null hypothesis is evidence of gender discrimination, or that men and women with the same levels of education, experience, and other economically relevant factors receive different pay. After testing for discrimination, the observed male-female wage gap is decomposed into two components: 1. that which results from male-female differences in economic characteristics, such as education; and 2. that which results from different pay structures, or discrimination. The answer to these questions will provide evidence as to whether the increase in wage inequality is resulting purely from managers rewarding more productive workers, and thus improving economic efficiency, or whether the increase in wage inequality is partially a result of managers rewarding non-economic characteristics and thereby hampering the transition.

\footnotetext{
${ }^{1}$ The Bulgarian Labor Flexibility Survey, completed in 1992, was based on 500 enterprises covering the manufacturing sector in four of the nine national districts, including Sofia.
} 
The plan of this paper is as follows. Section II reviews the characteristics of the 1995 Bulgaria Integrated Household Survey (BIHS), which is the data set used in this paper to test for gender discrimination. Section III discusses the methodology used to estimate wage functions. The most important aspect is that the semiparametric estimator used to estimate wages controls for selection and is robust to heteroscedasticity. Section IV reports the results, which show that women earn approximately 25 percent less than their male cohorts, and 85 percent of this difference is due to discrimination and not difference in economic performance. As this analysis is strictly cross sectional, I do not show that the increase in wage inequality has coincided with an increase in gender discrimination; but the results do show that the presence of gender discrimination is an important determinant of the level of wage inequality. Section $\mathrm{V}$ provides a brief conclusion.

\section{Data}

The data used in this paper are from the nationally representative Bulgaria Integrated Household Survey (BIHS) and were collected during the summer of 1995. The Gallup Organization in Sofia managed the survey and the World Bank provided technical assistance. The sample frame, from which the sample was drawn, is based on the 1992 general census of Bulgaria. The planned sample size was 2,500 households, which were randomly drawn in a twostage process. Not all households agreed to participate or could be located, and the actual sample size was 2,466 households with 7,199 individuals. The mid-year population count for 1995 was 8,272,339 persons (U.S. Census Bureau, Table 001, 2001), which means that the raising factor (ratio of population to sample size) is 1,149 . 
To focus on working age adults, I drop 2,491 persons from the sample who are less than 17 years of age or greater than 65 years of age. Narrowing the sample on age will not introduce selfselection bias as age is exogenous to the individual. I choose the lower bound of 17 years since school is compulsory through the age of 16 . Further, in the BIHS sample, there are no wage earners under 17 years of age who have completed their schooling. The upper age bound of 65 is higher than the official age of retirement, but the BIHS data indicate that many individuals continue to work for a wage after the age of retirement. Nonetheless, by excluding persons over 65 years of age, I lose less than 0.5 percent of the sample of wage earners.

I also drop 244 continuing students from the sample so that I only have working-age persons who have completed their schooling. There are 215 persons (less than five percent of the sample) that are missing wage, education, or household composition data, and I exclude these observations from the analysis. The resulting, effective sample size is 4,249 persons of which 44 percent $(1,874)$ are wage earners. In terms of the gender composition of the sample, $2,182(51$ percent) of the 4,249 persons are female, and 892 (48 percent) of the 1,874 wage earners are female. Sixty-nine percent of the effective sample, and 78 percent of the wage earners, live in urban areas.

\section{A. Wages}

Using the BIHS data, I construct gross wage income as the sum of wage payments (before taxes), wage adjustments for children, allowances for transportation costs, and other payments. To this sum, I add imputed values for paid leave and subsidized vacations. The resulting estimate of monthly, average wage income for the 1,874 wage earners is 6,822 Levs. This implies that yearly, per capita (using the 6,984 observations without missing data) wage income is 21,966 Levs. This estimate compares well with data from the National Statistical Institute (1998, Table 
V-1) which reports per capita, yearly wage income at 22,243 Levs in $1995 \mathrm{~g}^{\mathrm{G}}$ This is a difference of less than 1.3 percent, and is well within the sampling error of the surveys. The estimate of wages is then gross wage income divided by hours of wage work.

Relative to 1996 and 1997, inflation was quite low in 1995, with an annual rate of 33 percent. For the three-month span that the survey was in the field, the consumer price index rose by two percent (National Statistical Institute, 1998, Table VI-1). To correct for this, all reported prices have been deflated to the first month of the survey, May 1995. (This relatively small adjustment for inflation has little effect on the reported estimates.)

Likely to be of more importance than the temporal change in prices though, is the spatial differences in price levels. The National Statistical Institute does not report a spatial-price index, but it is widely assumed that the cost of living is much higher in Sofia city than elsewhere, and similarly that urban prices are higher than rural prices. For example, the World Bank (1996) asserts that the cost of living in Sofia is 23 percent greater than in the region of Haskovo, and further asserts that on average, urban prices are six percent higher than rural prices. Unfortunately the methodology used to construct these estimates is not documented, and there is no commonly accepted index for spatial price adjustment. Instead of using an undocumented index of spatial price variation, I will control for this price variation through the use of dummy variables for the political regions of Bulgaria, as well as a dummy for urban areas. 6

\footnotetext{
${ }^{5}$ The estimate of yearly wage income from the National Statistical Institute is very similar in construction to the estimate used in this paper. It is an aggregate measure of cash and in kind payments, and includes a value for annual vacations, public holidays, paid leave, overtime, and does not include tax payments.

${ }^{6}$ The BIHS sample covers nine political regions, including: Sofia City, Bourgas, Varna, Lovech, Montana, Plodviv, Russe, Sofia Region, and Haskovo.
} 


\section{B. Education}

Education levels in Bulgaria have historically been quite high with enrollment rates for primary and middle schools on par with (or better than) West European countries. In addition to successful enrollment rates, the Bulgarian schooling system was also characterized as providing girls access to the same opportunities as boys. (For more details on access and enrollment rates by gender see Laporte and Ringold, 1997.)

The BIHS data support the claim of similar access to schooling opportunities with education outcomes that are quite similar across gender. In 1995, the BIHS data show that the average level of schooling attained is 10.48 years for males and 10.40 years for females. The median (11 years) and interquartile range $(8,12$ years) of schooling attainment is the same across genders. As further evidence of equality of schooling outcomes, Figure 1 provides kernal density estimates of the male and female distributions of school attainment. Over the entire range of years of schooling, the distributions are very similar.

In order to specify educational attainment in the wage regression, it is useful to examine the Bulgarian schooling system. Education is compulsory for children up to the age of 16 (World Bank, 2000). Primary school begins at the age of six or seven and runs for four years. Middle school follows for four more years, and then at the end of grade eight, students are tested in Bulgarian and Mathematics. ${ }^{\mathrm{D}}$ The results of these tests determine in part, whether the students progress on to vocational, technical or more general academic, secondary school. ${ }^{8}$ Throughout the first half of the 1990s, approximately 40 percent of the enrolled secondary students attended

\footnotetext{
${ }^{7}$ In spite of the compulsory attendance requirements, the BIHS data show that 15 percent of the population between the ages of 17 and 65 have less than eight years of schooling.

${ }^{8}$ The post-middle school alternatives are actually a bit more complex. Secondary school options include gymnasium, which is an academic secondary school; specialist schools, which are also academically oriented but are more specialized and selective; technical schools, which have similar curriculum to gymnasium plus an additional year of vocational training; and finally vocational schools, which specialize in industrial skills and craft training. For more details, see World Bank (2000).
} 
general academic schools, while about 30 percent attended technical schools and the remaining 30 percent attended vocational schools (Laported and Ringold, 1997, Table 1).

In order to control for the various types of secondary schooling, I include in the wage regression model dummy variables that designate if the person attended a vocational, technical, or general secondary school. Similarly, in many countries the returns to primary schooling differ significantly from secondary schooling, and it is desirable to specify a functional form which allows for this possibility. (See Psacharopoulos, 1994, for returns to education by primary and secondary schooling for 78 countries.) I combine years of primary and middle school as one variable, and as a separate regressor, I combine years of secondary and post-secondary schooling. This break allows for some nonlinearity in the returns to years of schooling, and is also a reasonable break point given the institutional details of the Bulgarian schooling system.

\section{Estimation}

Wage equations are estimated using a standard Mincer equation, taking the form:

$$
\ln \left(\mathrm{w}_{\mathrm{i}}\right)=\beta_{1} \mathrm{~S}_{\mathrm{i}}+\beta_{2} \mathrm{E}_{\mathrm{i}}+\beta_{3} \mathrm{E}_{\mathrm{i}}^{2}+\boldsymbol{\beta}_{4} \mathbf{X}_{\mathrm{i}}+\varepsilon_{\mathrm{i}}
$$

where the i subscript denotes the individual, w is wages, $\mathrm{S}$ is years of schooling, E is experience, and $\mathbf{X}$ contains a set of variables to control for institutional characteristics. In particular, $\mathbf{X}$ contains dummy variables for the three types of secondary schooling since the value of a year of secondary schooling may differ if it is vocational, technical or general schooling. $\mathbf{X}$ also contains dummies for ten sectors of the economy, such as agriculture, manufacturing, construction, and science. Economic returns vary by sector, and the proportion of men and women in each sector 
varies, so it is useful to control for the sector of employment to estimate discrimination. Finally, $\mathbf{X}$ contains dummies for each of the nine political regions as well as a dummy for urban areas. These geographic differences will capture spatial price differences that are likely to affect wages.

As discussed above, my sample contains 4,249 working-age individuals of which 1,874 are wage earners. As is well known, OLS estimation of (1) on the sample of wage earners is likely to result in biased estimates due to sample selection. The sample selection problem is typically modeled as:

$$
\begin{aligned}
& \mathrm{w}^{*}=\mathrm{x}^{\prime} \beta+\varepsilon \\
& \mathrm{y}=\mathrm{z}^{\prime} \gamma+\mu
\end{aligned}
$$

where $\mathrm{w}^{*}$ is the unobserved wage offer, and $\mathrm{y}$ is a variable that indicates whether the individual is a wage earner. In the case of the Type II Tobit, y is a dummy variable; and for the Type III Tobit model, $\mathrm{y}$ is a continuous variable that is censored at zero with only positive outcomes observable. I use the log of hours worked in wage employment as y, thereby modeling wage determination as a Type III Tobit.

While $\mathrm{w}^{*}$ is what we are interested in estimating, we only observe wages for actual wage earners, w, or:

$$
\left.\begin{array}{ll}
\mathrm{w}=\mathrm{w}^{*} & \text { if } \mathrm{z}^{\prime} \gamma+\mu>0 \\
\mathrm{w}=0 & \text { otherwise }
\end{array}\right\}
$$

When estimating wages on the sample of wage earners, the conditional expectation of $\mathrm{w}^{*}$ is:

$$
\mathrm{E}\left(\mathrm{w}^{*} \mid \mathrm{x}, \mathrm{z}, \mathrm{y}>0\right)=\mathrm{x}^{\prime} \beta+\mathrm{E}\left(\varepsilon \mid \mathrm{x}, \mathrm{z}, \mu>-\mathrm{z}^{\prime} \gamma\right)
$$


and the zero-mean restriction placed on the error term, $\varepsilon$, will not in general hold. Heckman (1974) proposed a way to correct for this sample-selection bias and to restore the zero-mean property of the residual by adding a selection-bias-correction term, or Mill's ratio, to the regression. ${ }^{9}$ A problem with this approach, as discussed by Hurd (1979) and Nelson (1981), is that the Heckman estimator, along with the Tobit estimator, are biased when the assumption of homoscedastic errors is violated.

In the case of the BIHS data, as with most any multi-stage design survey, the assumption of homoscedastic residuals will rarely be tenable. One important reason that supports this assertion is that the clustering of observations from the multi-stage aspect of the sample design, results in observations that are more similar within clusters than across clusters. When the intra-cluster correlation is significantly greater than the inter-cluster correlation (and when the model does not account for the factors affecting the intra-cluster correlation), then the assumptions that the residuals are identically and independently distributed are most likely no longer valid. Deaton (1997, p. 79) asserts quite broadly, that: "It is a fact that regression functions estimated from survey data are typically not homoscedastic.”

Testing the assumption of homoscedasticity for the selection model is complicated somewhat by the issue of sample selection. The Breusch-Pagan test requires that the tested regression residual have a mean of zero. Pagan and Vella (1989) propose a modification to the BreuschPagan by first constructing 'generalized' residuals through any estimator of (1) that is robust to heteroscedasticity and then employing the standard Breusch-Pagan test. The p-value from the

\footnotetext{
${ }^{9}$ The parameters of this model can be estimated either by maximum likelihood or a two-step method.

${ }^{10}$ Arabmazar and Schmidt (1981) investigate the potential magnitude of the bias of the Tobit in the presence of heteroscedasticity and show that it can be quite large.
} 
Pagan-Vella test statistic estimating the wage regression strongly rejects the assumption of homoscedasticity $(\mathrm{p}<0.001)$.

Honoré et al. (1997) propose an estimator based on sample trimming for the Type III Tobit model which is robust to heteroscedasticity. They first make the general argument that the Type III Tobit is intuitively more appealing than the Type II Tobit as it exploits more information in the selection variable. In the model considered in this paper, I use the log of hours worked which indicates both whether the person selects into wage employment and also the intensity with which they are engaged in this activity.

The Honoré et al. estimator is conceptually similar to the Heckman two-step approach and employs the insights of Powell's (1986) trimmed estimators. In the first step, the selection equation, (3), is estimated via any estimator which will provide consistent estimates for the censored regression model in the presence of heteroscedasticity. They propose using either Powell's (1984) censored least absolute deviations (CLAD) estimator or Powell's (1986) symmetrically trimmed least squares (STLS) estimator.

The results from this estimation are then used to trim from the sample all observations where $\mathrm{y}$ is either equal to zero or greater than twice its predicted value, or in other words keep all observations where $0<y<2 z^{\prime} \hat{\gamma}$. The result of this trimming is that $\beta$ is now estimated only for the observations where $-\mathrm{z} \gamma<\mu<\mathrm{z} \gamma$, and this trimming restores the zero-mean condition on $\varepsilon$. The second stage of the Honore et al. estimator is to then estimate (2) on the trimmed sample using either ordinary least squares (OLS) or least absolute deviations (LAD).

For the first-stage estimates of the Honore et al. estimator, I use the STLS estimator rather than the CLAD estimator because the CLAD estimator requires that the median is observed. In 
the case of the BIHS data, the median is censored since only 44 percent of the working-age sample are wage earners. Powell's STLS estimator, which serves as conceptual motivation for the Honoré et al. estimator, is also found by trimming the data. OLS estimation of the censored dependent variable model is biased because the underlying error terms are not symmetrically distributed around zero. Powell motivates the STSL estimator by showing that symmetry around zero can be reintroduced by trimming observations with negative predicted values and replacing the dependent variable with twice its predicted value when the dependent variable is greater than twice the predicted value. More formally, he shows that the normal equation for this trimming is:

$$
0=\sum_{i=1}^{N} I\left(z_{i}^{\prime} \gamma>0\right)\left[\min \left(y_{i}, 2 z_{i}^{\prime} \gamma\right)-z_{i}^{\prime} \gamma\right] z_{i}
$$

where the indicator function, I, takes the value of one if the argument is true and zero otherwise. If $\gamma$ were known, the solution to this equation solves for the STSL estimator. Since $\gamma$ is not known, Powell states that minimizing the following objective function, $\mathrm{S}_{\mathrm{T}}(\gamma)$, implicitly yields a minimum to the normal equation, (6):

$$
\mathrm{S}_{\mathrm{T}}(\gamma)=\sum_{\mathrm{i}=1}^{\mathrm{N}}\left[\mathrm{y}_{\mathrm{i}}-\max \left(0.5 \mathrm{y}_{\mathrm{i}}, \mathrm{z}_{\mathrm{i}}^{\prime} \gamma\right)\right]^{2}+\sum_{\mathrm{i}=1}^{\mathrm{N}} \mathrm{I}\left(\mathrm{y}_{\mathrm{i}}>2 \mathrm{z}_{\mathrm{i}}^{\prime} \gamma\right)\left[\left(0.5 \mathrm{y}_{\mathrm{i}}\right)^{2}-\left(\max \left(0, \mathrm{z}_{\mathrm{i}}^{\prime} \gamma\right)\right)^{2}\right]
$$

The $\hat{\gamma}$ which minimizes $\mathrm{S}_{\mathrm{T}}(\gamma)$ is the STLS estimator. It is worth noting that the objective function does not explicitly trim the sample but rather penalizes observations where twice the predicted value is less than the observed value and observations with negative predicted values. The variance-covariance matrix for the STLS estimator is given by:

\footnotetext{
${ }^{11}$ Both estimators are consistent and asymptotically normal for a wide class of error distributions, but the CLAD is consistent to a wider class of error distributions and is more robust to outliers.
} 


$$
\frac{\sum_{i=1}^{N} I\left(z_{i}^{\prime} \gamma>0\right) \min \left(\mu_{i}^{2},\left(z_{i}^{\prime} \gamma\right)_{i}^{2}\right) x_{i} x_{i}^{\prime}}{\frac{1}{N}\left[\sum_{i=1}^{N} I\left(-z_{i}^{\prime} \gamma<\mu_{i}<z_{i}^{\prime} \gamma\right) x_{i} x_{i}^{\prime}\right]^{2}}
$$

I minimize (7) using ameoba (Ferrall, 1997), a simplex-based search method designed for minimizing non-differentiable likelihood functions. 12 To find starting values for the search algorithm, I use an iterative procedure that explicitly trims the sample in a way that imposes symmetry on the residuals. First, using OLS estimates on the full sample, I create a new dependent variable that is equal to the minimum of the dependent variable or twice the predicted value. I also drop all negative predicted values. I then repeat the OLS estimation on the new dependent variable and the trimmed sample, repeating until no more observations are dropped. The OLS estimates from the final iteration are used as the starting values for ameoba using the full sample and the true dependent variable.

The results from the STLS estimation inform about the selection decision into wage labor, (3), and are also used to trim the sample for the second step of the Honore et al. estimator for the Type III Tobit using symmetrically trimmed least squares (hereafter referred to as T3T-STLS). The purpose of the first-stage trimming is to restore the zero-mean condition of the residuals, and once restored, then OLS or LAD estimators will provide consistent point estimates for the wage equation, (2). The standard OLS estimate of the variance-covariance matrix, though, will be inconsistent since it does not account for the first-stage trimming of the sample. To provide consistent variance estimates, I bootstrap the parameters to estimate the empirical density

\footnotetext{
${ }^{12}$ The simplex or polytope method is derived by Nelder and Mead (1965) and code for ameoba is based on Press $e t$ al. (1987). (Polytope is the preferred term in the optimization literature to avoid confusion between the simplex method used for linear programming and the method described by Nelder-Mead.)
} 
function and the variance-covariance matrix. ${ }^{13}$ The bootstrap parameter estimates are found by resampling the design matrix and then for each sample following the two-step method to solve for the T3T-STLS estimates. To denote the precision of the point estimates, I provide two measures from the bootstrap method. The first is the standard error of the empirical density function of the parameter estimate. For the second measure of precision, I superscript the parameter estimates with $* * *$, or $* * *$ if the (two-tailed) $90^{\text {th }}, 95^{\text {th }}$, or $99^{\text {th }}$ percentile of the biascorrected empirical density function excludes zero.

\section{Results}

\section{A. Selection Model and Wage Estimates}

Identification of the selection model requires finding variables that explain the decision to work in the wage sector, but are not directly determinants of wages. Becker's (1965) model of time allocation suggests that one factor influencing the reservation wage and thereby the decision to participate will be non-employment income. The BIHS data have information on the net level of remittance income, income from real estate assets, and the amount of social assistance income in the household. In addition to these three variables, I follow Heckman's (1974) original work on the selection of women into the wage market, and include the number of young children (all ages up to five) and the number of older children (older than five and less than 14). The motivation is that younger children require care, and older children have the potential to supply labor for household work.

Table 1 presents the STLS estimates of the selection model where the dependent variable is the log of hours in wage work. This variable is censored at zero if the individual does not engage

\footnotetext{
${ }^{13}$ For a general discussion of the bootstrap, see Efron and Tibshirani (1993).
} 
in wage employment and therefore has zero wages for the second-stage, wage regressions. As the purpose of this paper is to examine wage differentials by gender, I estimate the wage and selection models for men and women separately as well as for the combined sample.

For all three models, the non-wage income variables and/or the family composition variables are significant. In the case of the combined sample of men and women, the number of children in the family up to four years of age is negative and significant (p.0.045) suggesting that increased number of children decreases an adult's ability to engage in the wage sector. The results for men differ somewhat in that the family composition variables have no effect on their decision to participate in the wage sector, but increased levels on non-wage income for the family reduces the men's hours in wage labor. In particular, remittance and social benefit income both have negative effects (of similar magnitude) and both are significant ( $\mathrm{p}_{\text {remittance. }} 0.05$ and $\mathrm{p}_{\text {social }}$ benefit.0.09).

In the case of women, young children (zero to four years of age) have a large and significant negative effect on participation while mid-aged children (five to 14 years of age) have a positive effect. This finding suggests that women reduce their wage participation hours to tend to young children, and mid-aged children free up some of the time demands placed on women allowing them to work more in the wage sector. Women's participation in the wage sector is also affected by non-wage income. Rents from real estate have a negative and significant effect, while increased levels of social benefits has a counter intuitive positive effect.

Table 2 presents the wage regression results with the sample selection correction through the trimming method. The first column presents the national estimates with a dummy variable for

\footnotetext{
${ }^{14}$ I provide no rigorous explanation for this result, but it seems possible that it is linked to the result that men work less with increased levels of social benefit income and that most women are in households with a male spouse who is about three years older. It is also possible that men are more likely to be disabled from work, which increases social benefits, but not by an amount sufficient to support the family which requires that women must work.
} 
whether the individual is male or female. The point estimate on the female dummy suggests that women's wages are 18 percent lower than men's wages even after controlling for schooling, type of secondary school, experience, sector of employment, and region of residence. This estimate though, is a bit naïve as it assumes that the only difference between the wage determinants is in the intercept and that all of the slope parameter estimates are the same.

To allow for the likely event that the difference in pay between men and women is affected by more than just a shift in the intercept, the second and third columns in Table 2 estimate gender-specific wage regressions. From these results it is clear that there are important differences. The Hausman test statistic, $\left(\hat{\beta}_{\text {female }}-\hat{\beta}_{\text {male }}\right)^{\prime}\left(\hat{\mathrm{V}}_{\text {female }}-\hat{\mathrm{V}}_{\text {male }}\right)^{-1}\left(\hat{\beta}_{\text {female }}-\hat{\beta}_{\text {male }}\right)$, strongly rejects the assumption that parameter estimates for the female regression, $\hat{\beta}_{\text {female }}$, are equal to those from the male wage regression, $\hat{\beta}_{\text {male }}$, with a $\mathrm{p}$-value equal to $4.3 \mathrm{e}-10$.

More specifically, the intercept for men is greater than for women, which is not too surprising given the point estimate on the female dummy in the pooled sample. This statement, of course, needs to be tempered by noting that there are several control variables for sector of employment and regions, and it is possible that wage differentials will be more pervasive in certain areas or jobs. In terms of experience and education, though, women receive greater returns (as a percent of their wages) from experience and secondary schooling. The rate of return to an additional year of secondary schooling for women is 8.1 percent in contrast to 4.9 percent for men.

The evidence of a heteroscedastic error structure found above, implies that the standard Heckman selection estimates (whether two-step or maximum likelihood) are inconsistent. Nonetheless, it is still reasonable to ask whether the consistent T3T-STLS differ significantly from the Heckman estimates. The Hausman test statistic for comparing the male regression 
results across the two estimators is 120 with 26 degrees of freedom and a p-value of 5.2e-14.

Similarly, the Hausman test statistic comparing the Heckman female estimates with the T3TSTLS female estimates is 80 and this has a p-value of $2.1 \mathrm{e}-7$. For both the male and female regression results, the Hausman tests strongly reject the null hypothesis that the Heckman estimates are equal to the T3T-STLS estimates.

\section{B. Oaxaca Decomposition}

Given the differences across the male and female estimates for the wage functions, Oaxaca (1973) proposed a method to decompose the observed gender wage gap into two components: 1. That resulting from differences in education and experience levels (and any other explanatory variable) of men and women; and 2. That resulting from current labor-market discrimination. 15 More specifically, let $\ln (\overline{\mathrm{w}})$ be the $\log$ of mean wages, and let the subscripts $\mathrm{m}$ and $\mathrm{f}$ denote male and female. Then, since the regression line passes through the means, the mean difference in logs between male and female wages can be written as:

$$
\begin{aligned}
& \ln \left(\overline{\mathrm{W}}_{\mathrm{m}}\right)-\ln \left(\overline{\mathrm{W}}_{\mathrm{f}}\right)=\left(\overline{\mathrm{x}}_{\mathrm{m}}^{\prime}-\overline{\mathrm{x}}_{\mathrm{f}}^{\prime}\right) \hat{\beta}_{\mathrm{m}}+\overline{\mathrm{x}}_{\mathrm{f}}^{\prime}\left(\hat{\beta}_{\mathrm{m}}-\hat{\beta}_{\mathrm{f}}\right) \\
& \begin{array}{llll}
0.22 & =0.03+0.19
\end{array}
\end{aligned}
$$

or, similarly this can be expressed as:

$$
\begin{array}{cccc}
\ln \left(\overline{\mathrm{w}}_{\mathrm{m}}\right)-\ln \left(\overline{\mathrm{w}}_{\mathrm{f}}\right) & = & \left(\overline{\mathrm{x}}_{\mathrm{m}}^{\prime}-\bar{x}_{\mathrm{f}}^{\prime}\right) \hat{\beta}_{\mathrm{f}} & +\bar{x}_{\mathrm{m}}^{\prime}\left(\hat{\beta}_{\mathrm{m}}-\hat{\beta}_{\mathrm{f}}\right) \\
0.22 & = & -0.01 & +
\end{array}
$$

\footnotetext{
${ }^{15}$ Certainly differences in levels of education and experience could be the result of discrimination, but the focus of this paper is strictly on discrimination in how the labor market rewards men and women. It is also important to note that this 'discrimination' component is that part of the wage gap that can not be explained by the differences in endowments and results from the differences in the estimated returns by gender. Its accuracy as a measure of discrimination is a function of how well the model is specified.
} 
The difference between (9) and (10) is simply an issue of whether to treat the male or female wage structure as the basis for comparison, which is an index-number problem that does affect the interpretation of the results. In Oaxaca's (1973) original work, using the male wage structure as the base implied that 53 percent of the log wage gap was due to discrimination, while using the female wage structure implied that 64 percent of this gap was due to discrimination.

The results from estimating (9) and (10) using the regression estimates from Table 2 are listed below each of the equations. The observed difference in the $\log$ of the means is equal to 0.22 , or the average male salary is 25 percent greater than the average female salary. The first component on the right-hand side of (9) and (10) indicates how much of this observed malefemale wage gap is explained by differences in observed characteristics such as education and experience. Equation (9) shows that if the wage differential were only due to differences in observable characteristics, the male-female gap (in terms of the log of mean wages) would be 0.03. Equation (10) indicates that if the differential were only due to differences in characteristics, then the gap would be -0.01 - women would receive higher mean wages.

The second component of (9) and (10) provides a measure of discrimination. This component shows how much of the observed wage gap is due to the different ways in which men and women are rewarded for their characteristics. Equation (9) indicates that the log difference in mean wages due to the different payment structures for men and women is equal to 0.19 , while (10) estimates this measure to be 0.23 . The estimate from (9) implies that discriminatory labor markets result in men being paid 21 percent more than women, while (10) indicates that men are paid 26 percent more.

Neumark (1988) argues that the appropriate base wage structure depends on what one believes is happening in the labor market. If women are being paid competitively, but men are 
the recipients of favoritism, then the female wage structure should be used as the base, as in (10). If, on the other hand, women are being 'underpaid', or discriminated against, then the male wage structure should be used as the base, as in (9). ${ }^{16}$ In the case of the tight labor market in Bulgaria with falling wages and rising unemployment, I consider the conceptual framework of men being paid competitively and women being underpaid somewhat more compelling. For this reason, and for the sake of being somewhat conservative, my preferred estimate is that men receive wages that are 21 percent higher than women resulting from discriminatory labor markets.

The Oaxaca decomposition sheds light on average wage differences due to differences in average characteristics and wage structures. Averages can be misleading, though, if the wage distributions for men and women look dramatically different. The left-hand panel of Figure 2 presents a kernal density estimate of the log of wages for men and women. The two distributions appear to be fairly similarly shaped, except that the female wage distribution is shifted to the left. The right-hand panel presents the same diagram except that female wages have been increased by 21 percent to compensate for the discriminatory practices of the labor market. This panel makes quite clear that gender discrimination accounts for most of the difference between male and female wages across all points of the distribution.

As a final simulation, I examine to what extent the inequality in wages would decline if women were to be paid according to the male wage structure. First, I construct an estimate of predicted, log wages using the separate models for men and women found in Table 2. I call this the real predicted wage. Then I predict log wages for both men and women, but this time using

\footnotetext{
${ }^{16}$ Neumark (1988) also shows that if employers preferences for the male-female composition of their labor force are homogeneous of degree zero, then the appropriate index for the nondiscriminatory wage structure is the parameter estimates from the pooled sample. Appleton et al. (1999) provide a critique of the Neumark decomposition arguing that there is no empirical evidence supporting the assumption of hiring preference which are homogeneous of degree zero. In the case of Bulgaria, there is some evidence suggesting the contrary-female participation rates fell from 93 to 81 percent between 1989 and 1991 (SzirDczki and Windell, 1992). Participation, of course, reflects preferences of workers and firms, but this nonetheless shows a dramatic change in the male-female composition of the labor force.
} 
only the parameter estimates for the male model. This provides estimates of what men and women would earn if they all were paid according to the male wage structure, and I refer to this as the discrimination-free predicted wage.

Any estimate of inequality will be low for both the real predicted wage and the discrimination-free predicted wage since the log transformation greatly reduces dispersion, and similarly predicted values will further reduce dispersion. Nonetheless, examining how measures of inequality change when comparing the two measures does provide some insight into the extent to which discrimination worsens wage inequality. The BIHS data indicate that the Gini coefficient and the coefficient of variation for the discrimination-free predicted wage is 18 percent lower than for the actual predicted wage. Further, the Theil measure of entropy, which weights the tails of the distribution more heavily than the Gini, declines by 34 percent when actual predicted wages are transformed into discrimination-free predictions.

\section{Conclusion}

Bulgaria's transition to a market economy has resulted in a large increase in wage inequality. Given the emphasis on wage leveling in pre-transition Bulgaria, it is possible that increasing wage inequality, resulting from rewarding more productive workers, was required to improve efficiency. It is also possible, though, that the increase in wage inequality results from managers rewarding non-economic characteristics. This paper first examines the extent to which discrimination explains the gender wage differential in Bulgaria, and then examines the extent to which discrimination affects wage inequality. The preferred estimates show that male wages are about 25 percent greater than female wages. An Oaxaca decomposition of this differential shows that differences in economic characteristics, such as education, experience, or sector of 
employment, explains very little of this wage differential. To a large extent this is due to the fact that there is a history of equal access to education and employment opportunities in Bulgaria.

The large majority, the preferred estimates indicate 85 percent, of this wage differential is explained by what is typically referred to as discriminatory practices. More accurately this difference is explained by the difference in the wage structures for men and women, or how men and women are rewarded differently for the same economic characteristics.

Figure 2 indicates that the distribution of wages would be essentially the same for women and men if all women received an increase in wages of 21 percent to compensate for the discriminatory practices. Similarly, if women were paid according to the male wage schedule, the level of wage inequality would decline significantly. In considering the log of predicted wages, the Gini coefficient declines by 18 percent when female wages are predicted using the male wage structure. 


\section{REFERENCES}

Appleton, Simon; Hoddinott, John and Krishnan, Pramila. "The Gender Wage Gap in Three African Countries.” Economic Development and Cultural Change, January 1999, 47(2): 289312.

Arabmazar, Abbas and Schmidt, Peter. "Further Evidence on the Robustness of the Tobit Estimator to Heteroskedasticity." Journal of Econometrics, November 1981, 17: 253-258.

Becker, Gary. "A Theory of the Allocation of Time.” Economic Journal, September 1965, 75(299): 493-517.

Beleva, Iskra; Jackman, Richard and Nenova-Amar, Mariela. "Bulgaria." Chapter 5 in Unemployment, Restructuring, and the Labor Market in Eastern Europe and Russia, Commander, S. and Coricelli, F. (eds.), Washington, DC: The World Bank, 1995.

Blau, Francine and Kahn, Lawrence. "The Gender Earnings Gap: Learning from International Comparisons." American Economic Review (papers and proceedings), May 1992, 82(2): 533-538.

Commander, Simon and Tolstopiatenko, Andrei. "Enterprise Restructuring and the Structure of Compensation: Why is Unemployment Low in the FSU?" mimeo, World Bank, January 1996.

Deaton, Angus. The Analysis of Household Survey. Baltimore: John Hopkins, 1997.

Efron, Bradley and Robert Tibshirani. An Introduction to the Bootstrap. Monographs on Statistics and Applied Probability, 57, New York: Chapman Hall, 1993.

Ferrall, Christopher. "Routines to Maximize a Function.” Stata Technical Bulletin, 1997, STB-38 (sg71): 22-26.

Heckman, James. "Shadow Prices, Market Wages, and Labor Supply.” Econometrica, July 1974, 42(4): 679-694.

Honoré, Bo; Kyriazidou, Ekatirini and Udry, Christopher. "Estimation of Type 3 Tobit Models Using Symmetric Trimming and Pairwise Comparisons." Journal of Econometrics, JanuaryFebruary 1997, 76(1-2): 107-128.

Hurd, Michael. "Estimation in Truncated Samples When There is Heteroscedasticity." Journal of Econometrics, October/December 1979, 11(2/3): 247-258.

Jasso, Guillermina. "Trends in the Experience of Injustice: Justice Indexes about Earnings in Six Societies, 1991-1996.” Social Justice Review, 2000, 13(2): 101-121. 
Jones, Derek. "The Bulgarian Labour Market in Transition.” International Labour Review, 1991, 131(2): 211-226.

Laporte, Bruno and Ringold, Dena. "Trends in Education Access and Financing during the Transition in Central and Eastern Europe.” World Bank Technical Paper No. 361, Social Challenges of Transition Series, April 1997, The World Bank.

Milanovic, Branko. Income, Inequality and Poverty during the Transition from Planned to Market Economy. Washington, D.C.: The World Bank, 1998.

Milanovic, Branko. "Explaining the Increase in Inequality during the Transition." Economics of Transition, 1999, 7(2): 299-341.

National Statistical Institute. Statistical Yearbook 1998. Republic of Bulgaria, Sofia.

Nelder, J.A. and Mead, R. "A Simplex Method for Function Minimization.” The Computer Journal, 1965, 7: 308-313.

Nelson, Forrest. "A Test for Misspecification in the Censored Normal Model." Econometrica, September 1981, 49(5): 1317-1329.

Neumark, David. 'Employers' Discriminatory Behavior and the Estimation of Wage Discrimination.” Journal of Human Resources, 1988, 23(3): 279-295.

Oaxaca, Ronald. "Male-Female Wage Differentials in Urban Labor Markets." International Economic Review, October 1973, 14(3): 693-709.

Orazem, Peter and Vodopivec, Milan. "Male-Female Differences in Labor Market Outcomes During the Early Transition to Market: The Cases of Estonia and Slovenia." Journal of Population Economics May 2000, 13(2): 283-303.

Pagan, Adrian and Vella, Frank. 1989. "Diagnostic Tests for Models Based on Individual Data: A Survey." Journal of Applied Econometrics. 4: s29-s59.

Powell, James. "Least Absolute Deviations Estimation for the Censored Regression Model." Journal of Econometrics, July 1984, 25(3): 303-325.

Powell, James, "Symmetrically Trimmed Least Squares Estimation for Tobit Models." Econometrica, November 1986, 54(6): 1435-1460.

Press W.H.; Flannery, B.P.; Teukolsky, S.A. and Vetterling, W.T. Numerical Recipes: The Art of Scientific Computing. Cambridge: Cambridge University Press, 1987.

Psacharopoulos, George. "Returns to Investment in Education: A Global Update." World Development, 1994, 22 (9): 1325-1343. 
Sziráczki, György and Windell, James. "Impact of Employment Restructuring on Disadvantaged Groups in Hungary and Bulgaria.” International Labour Review, 1992, 131(405): 471-496.

U.S. Census Bureau, International Data Base. Table 001: Total Midyear Population, 2001. (http://www.census.gov/ipc/www/idbnew.html)

World Bank. "Note on Consumption and Income Aggregates." Mimeo, Bulgaria Integrated Household Survey, Basic Documentation, 1996.

World Bank. "Bulgarian-Education Modernization Project.” Program Information Document, Report No. PID8735, February 2000. 
Table 1: Log Hours in Wage Work, The Selection Model (Symmetrically Trimmed Least Squares)

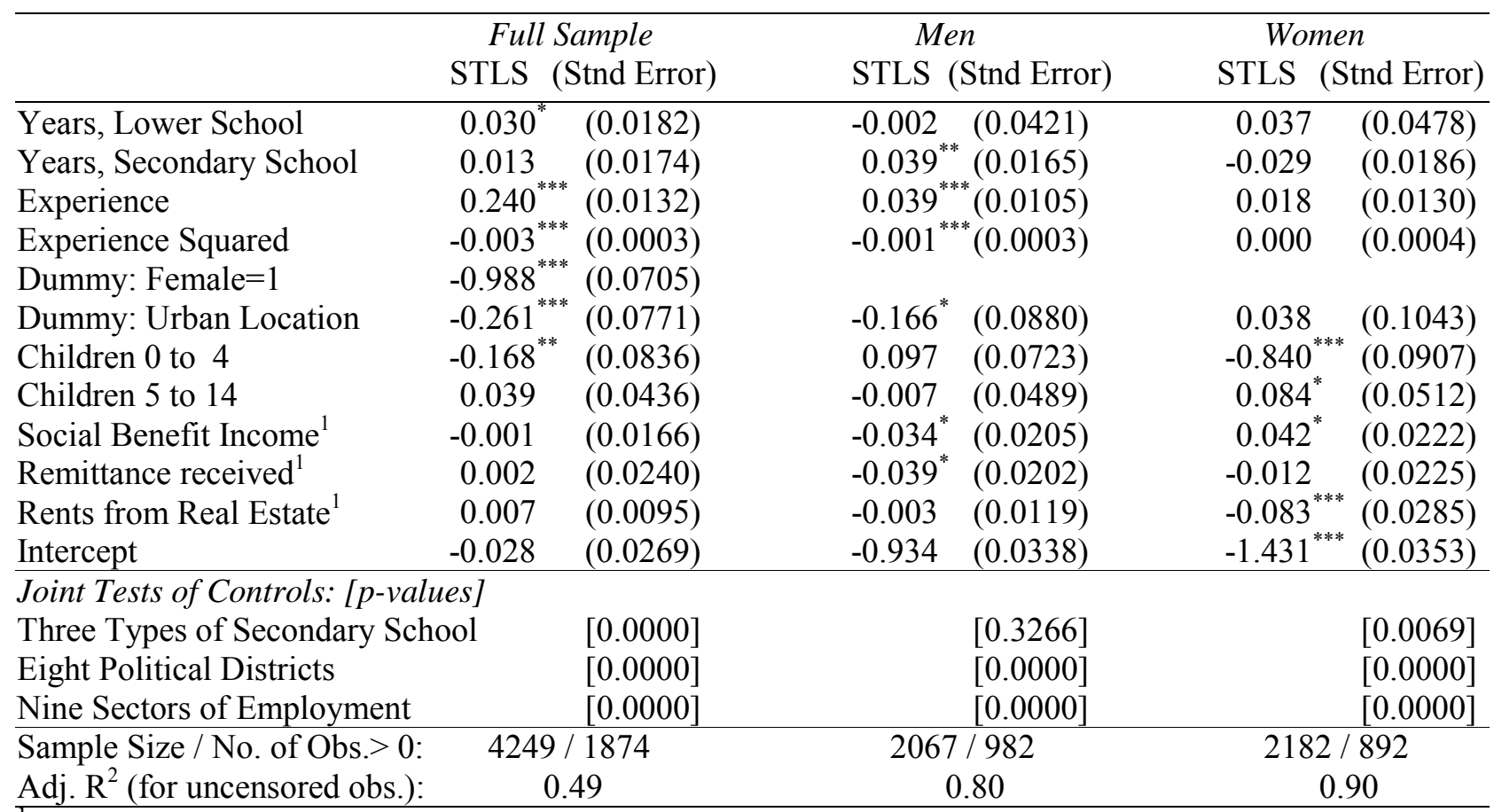

${ }^{1}$ Non-wage income is Levs/1000.

Notes: Dependent variable is the log of hours in wage employment, which serves as indication of both whether the individual is engaged in wage labor and also the intensity. Adjusted $\mathrm{R}^{2}$ is calculated only for the positive observations (excludes censored observations). Parameters are superscripted with $*, * *$, or $* * *$ if the absolute value of the p-value is less than $0.1,0.05$, or 0.01 . 
Table 2: Wage Regression Model, Returns to Primary and Secondary Schooling (Type III Tobit with Symmetrically Trimmed Least Squares, T3T-STLS)

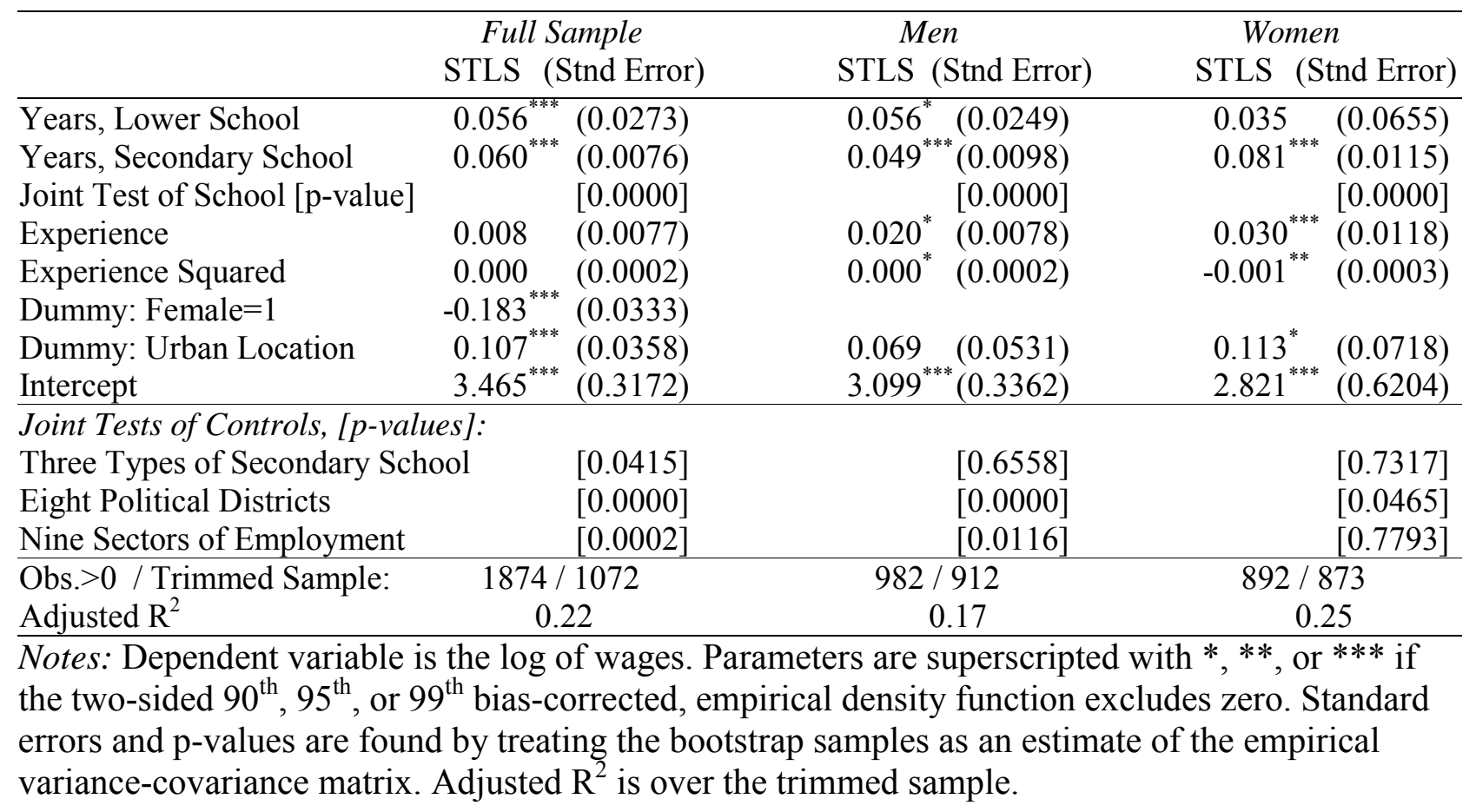


William Davidson Institute Working Paper 401

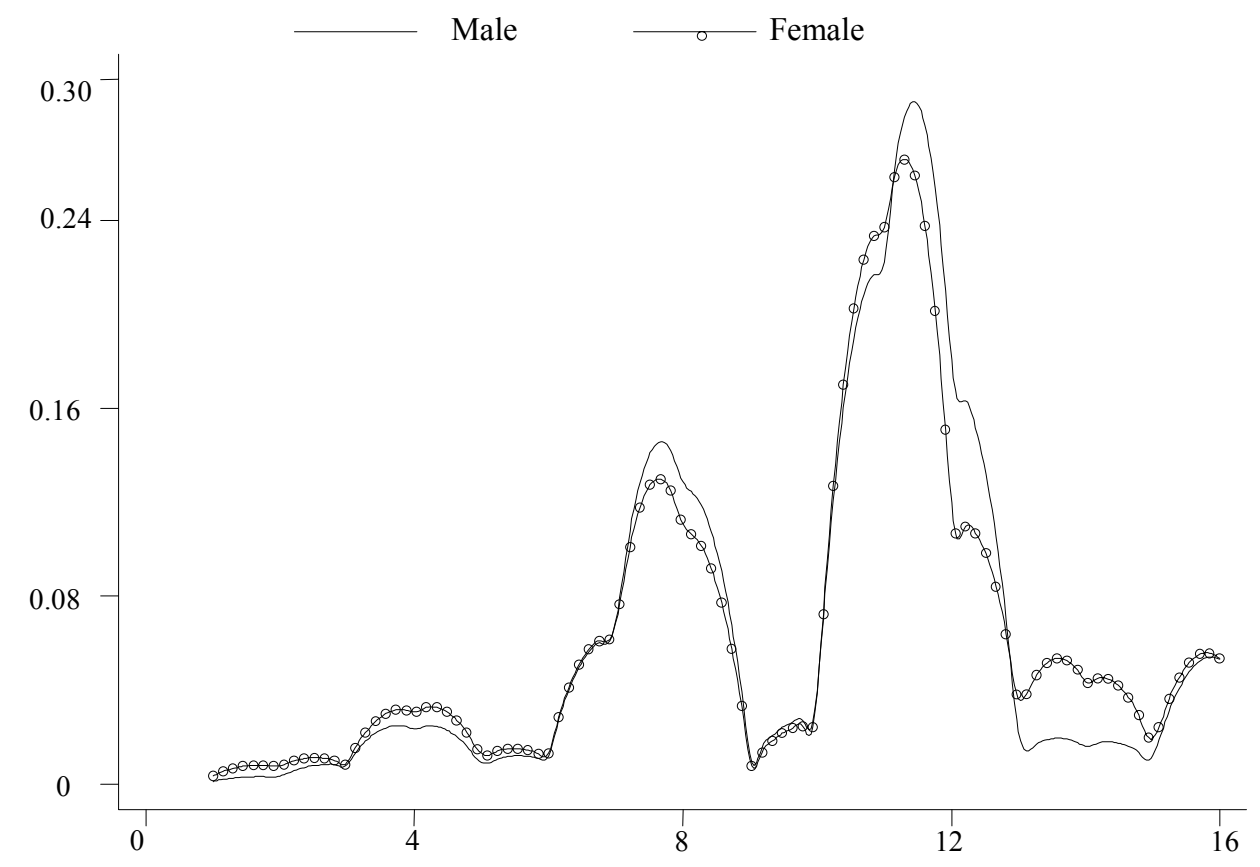

Figure 1: Years of Schooling by Gender, Kernel Estimate of the Density Function

Notes: Tails of the distribution are trimmed at the $1^{\text {st }}$ and $99^{\text {th }}$ percentile resulting in a sample size of 2,088 women and 1,982 men. The Epanechnikov kernal is used with a bandwidth of 0.46. This width is 80 percent of the optimal width for estimating the density of a normally distributed variable with the Gaussian kernal. 
William Davidson Institute Working Paper 401
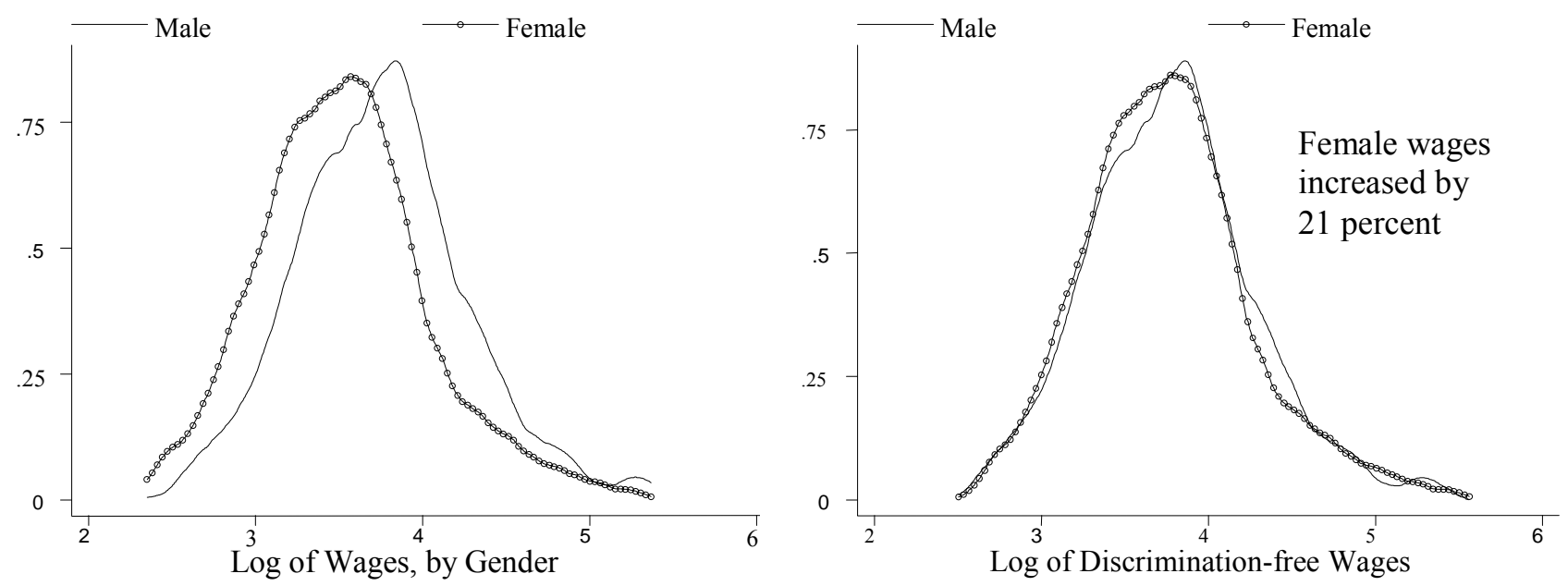

Figure 2: Distribution of Wages by Gender, Kernel Estimate of the Density Function

Notes: Tails of the distribution are trimmed at the $1^{\text {st }}$ and $99^{\text {th }}$ percentile resulting in a sample size of 861 female and 962 male wage earners. The Epanechnikov kernal is used with a bandwidth of 0.09 . This width is 90 percent of the optimal width for estimating the density of a normally distributed variable with the Gaussian kernal. 


\section{DAVIDSON INSTITUTE WORKING PAPER SERIES - Most Recent Papers}

The entire Working Paper Series is available at: www.wdi.bus.umich.edu

CURRENT AS OF 11/9/01

\begin{tabular}{|c|c|c|}
\hline Publication & Authors & Date \\
\hline $\begin{array}{l}\text { No. 401: The Gender Wage Gap in Bulgaria: A Semiparametric } \\
\text { Estimation of Discrimination }\end{array}$ & Dean Jolliffe & July 2001 \\
\hline $\begin{array}{l}\text { No. 400: Do External Auditors Perform a Corporate Governance Role in } \\
\text { Emerging Markets? Evidence from East Asia }\end{array}$ & Joseph P. H. Fan and T.J. Wong & Oct. 2001 \\
\hline $\begin{array}{l}\text { No. 399: Financial Conditions and Investment during the Transition: } \\
\text { Evidence from Czech Firms }\end{array}$ & Lubomír Lízal and Jan Svejnar & Oct. 2001 \\
\hline $\begin{array}{l}\text { No. 398: Accessible Pareto-Improvements: Using Market Information to } \\
\text { Reform Inefficiencies }\end{array}$ & Michael Mandler & May 2001 \\
\hline No. 397: The Making of an Integrated National Grain Market in China & Wubiao Zhou & Oct. 2001 \\
\hline No. 396: Corruption and Resource Allocation: Evidence from China & Wei Li & June 2001 \\
\hline $\begin{array}{l}\text { No. 395: Government Shareholding and the Value of China's Modern } \\
\text { Firms }\end{array}$ & Lihui Tian & Apr. 2001 \\
\hline No. 394: Labor Hoarding in Russia: Where Does it Come from? & $\begin{array}{l}\text { Rouslan Koumakhov and Boris } \\
\text { Najman }\end{array}$ & June 2000 \\
\hline $\begin{array}{l}\text { No. 393: Ownership Structure, Corporate Governance, And Firm Value: } \\
\text { Evidence from the East Asian Financial Crisis }\end{array}$ & Michael Lemmon and Karl Lins & Apr. 2001 \\
\hline No. 392: Marshall and Labour Demand in Russia: Going Back to Basics & $\begin{array}{l}\text { Jozef Konings and Hartmut } \\
\text { Lehmann }\end{array}$ & Aug. 2001 \\
\hline No. 391: Economic Transition and Elections in Poland & $\begin{array}{l}\text { John E. Jackson, Jacek Klich, and } \\
\text { Krystyna Poznańska }\end{array}$ & June 2001 \\
\hline $\begin{array}{l}\text { No. 390: Effects of Bank Insolvency and Strategic Uncertainty on } \\
\text { Corporate Restructuring in Transition Economies }\end{array}$ & Christa Hainz & Aug. 2001 \\
\hline No. 389: Mark-Up Pricing In Bulgarian Manufacturing & $\begin{array}{l}\text { Rumen Dobrinsky, Boyko } \\
\text { Nikolov, and Nikolay Markov }\end{array}$ & June 2001 \\
\hline $\begin{array}{l}\text { No. } 388 \text { Globalization and Firms' Financing Choices: } \\
\text { Evidence from Emerging Economies }\end{array}$ & $\begin{array}{l}\text { Sergio Schmukler and Esteban } \\
\text { Vesperoni }\end{array}$ & May 2001 \\
\hline $\begin{array}{l}\text { No. } 387 \text { The Distributional Impacts of Indonesia's Financial Crisis on } \\
\text { Household Welfare: A “Rapid Response” Methodology }\end{array}$ & $\begin{array}{l}\text { Jed Friedman and James } \\
\text { Levinsohn }\end{array}$ & Sept. 2001 \\
\hline $\begin{array}{l}\text { No. } 386 \text { Corporate Financial Policies and Performance Prior to Currency } \\
\text { Crises }\end{array}$ & $\begin{array}{l}\text { Arturo Bris, Yrjö Koskinen, and } \\
\text { Vicente Pons }\end{array}$ & June 2001 \\
\hline No. 385 Ownership and Productive Efficiency: Evidence from Estonia & Derek C. Jones and Niels Mygind & Aug. 2001 \\
\hline $\begin{array}{l}\text { No. } 384 \text { Forthcoming in: Journal of Economic Perspectives, } \\
\text { "Institutional Determinants of Labor Reallocation in Transition" Vol. } \\
\text { 16, No. 2, Feb. } 2002 \text {. }\end{array}$ & Tito Boeri and Katherine Terrell & June 2001 \\
\hline $\begin{array}{l}\text { No. } 383 \text { Deindustrialisation and Structural Change During the Post- } \\
\text { Communist Transition }\end{array}$ & $\begin{array}{l}\text { Tomasz Mickiewicz and Anna } \\
\text { Zalewska }\end{array}$ & June 2001 \\
\hline No. 382 Markets and Growth & Štěpán Jurajda and Janet Mitchell & July 2001 \\
\hline $\begin{array}{l}\text { No. } 381 \text { Labor Market Discrimination During Post-Communist } \\
\text { Transition: A Monopsony Approach to the Status of Latvia's Russian } \\
\text { Minority }\end{array}$ & Robert S. Chase & Sept. 2000 \\
\hline No. 380 Dollarization of Liabilities in Non-tradable Goods Sector & Frédéric Chabellard & June 2001 \\
\hline $\begin{array}{l}\text { No. } 379 \text { Lessons from the Russian Meltdown: The Economics of Soft } \\
\text { Legal Constraints }\end{array}$ & Enrico Perotti & Mar. 2001 \\
\hline No. 378 Effective Tax Rates in Transition & Vlad Ivanenko & May 2001 \\
\hline $\begin{array}{l}\text { No. } 377 \text { Some Explanations for Changes in the Distribution of } \\
\text { Household Income in Slovakia: } 1988 \text { and } 1996\end{array}$ & $\begin{array}{l}\text { Thesia Garner and Katherine } \\
\text { Terrell }\end{array}$ & May 2001 \\
\hline $\begin{array}{l}\text { No. } 376 \text { Competition and Enterprise Performance in Transition } \\
\text { Economies: Evidence from a Cross-country Survey }\end{array}$ & $\begin{array}{l}\text { Wendy Carlin, Steven Fries, } \\
\text { Mark Schaffer and Paul Seabright }\end{array}$ & May 2001 \\
\hline $\begin{array}{l}\text { No. } 375 \text { Why More is Actually Less: New Interpretations of China's } \\
\text { Labor-Intensive FDI }\end{array}$ & Yasheng Huang & May 2001 \\
\hline
\end{tabular}

